\title{
Virus production in Phaeocystis pouchetii and its relation to host cell growth and nutrition
}

\author{
Gunnar Bratbak ${ }^{1, *}$, Anita Jacobsen², Mikal Heldal ${ }^{1}, K^{2}$ Keizo Nagasaki ${ }^{3}$, \\ Frede Thingstad $^{1}$
}

\author{
${ }^{1}$ Department of Microbiology, University of Bergen, Jahnebakken 5, N-5020 Bergen, Norway \\ ${ }^{2}$ Department of Fisheries and Marine Biology, University of Bergen, Bergen High Technology Centre,
} N-5020 Bergen, Norway

${ }^{3}$ Red Tide Biology Section, Red Tide Research Division, Nansei National Fisheries Research Institute, 2-17-5 Maruishi, Ohno, Saeki, Hiroshima 739-04, Japan

\begin{abstract}
In this experimental study we investigated how growth conditions and physiological status of the marine haptophyte Phaeocystis pouchetii affect its interaction with the lytic virus PpV01. A simple mathematical model describing the infection, the lysis of algae and the production of new viral particles was developed as an aid for analyzing and understanding the interaction between host and virus. $P$. pouchetii was susceptible to virus infection in all stages of growth. Nutrient or light limitation of algal growth did not inhibit viral reproduction and cell lysis. Neither the infectivity of the progeny viruses produced nor the length of the lytic cycle appeared to be affected by the host cells' growth condition. However, possible effects may have been obscured by low accuracy of infective virus counts or by low sampling frequency. The host cells' growth conditions did have a significant impact on burst size. A maximum of 510 viruses produced per infected host cell was found in exponentially growing cultures, while low burst size (minimum 15) was found in stationary phase cultures, in nutrient depleted cultures and in light limited cultures.
\end{abstract}

KEY WORDS: Phaeocystis pouchetii $\cdot$ Virus · Nutrients · Growth condition

\section{INTRODUCTION}

Viruses infecting bacteria, phytoplankton and other microorganisms have been recognized as active partners in the microbial food web (Fuhrman \& Suttle 1993, Thingstad et al. 1993). In marine ecosystems total counts of viruses and virus-like particles (VLP) are usually reported to be in the range of $10^{6}$ to $10^{8} \mathrm{ml}^{-1}$ (Maranger \& Bird 1995). Most of these are presumably bacteriophages (Bratbak et al. 1990) but viruses infecting eucaryotic microalgae and cyanobacteria may also be present in significant numbers (Proctor \& Fuhrman 1990, Bratbak et al. 1993, Suttle \& Chan 1993, 1995, Waterbury \& Valois 1993). The possible ecological significance of viruses as a cause of phytoplankton mor-

\footnotetext{
·E-mail: gunnar.bratbak@im.uib.no
}

tality in natural waters has been inferred from several kinds of observations: the presence of algal cells containing virus-like particles in natural communities (for review see van Etten et al. 1991, Reisser 1993, Zingone 1995; the presence of viruses in natural waters infecting specific algal populations (Suttle et al. 1990, Cottrell \& Suttle 1991, Suttle 1992, Suttle \& Chan 1993. 1995, Waterbury \& Valois 1993); and studies of population dynamics showing that a decrease in one algal population may be accompanied by an increase in virus abundance (Bratbak et al. 1993, 1995).

In natural marine ecosystems, phytoplankton mortality and the fate of phytoplankton blooms are most often considered to be caused by zooplankton grazing or sedimentation (e.g. Walsh 1983), but mass cell lysis has also been observed (Brussaard et al. 1995). The growth conditions (nutrient availability, light regime, etc.) and the physiological state of the phytoplankton popula- 
tion may affect sinking and suspension of the cells in the water column (Walsby \& Reynolds 1980), and the same factors may presumably also affect cell death and lysis. Moreover, the cells' susceptibility to virus infection and the rate of virus proliferation may also be affected. Since the mechanism of bloom collapse (sedimentation, grazing or cell lysis) may have a profound impact on the fate of the algal biomass in the food web, it will be important to learn how these mechanisms are regulated.

Few experimental studies have been conducted to elucidate, from an ecological point of view, the impact of growth conditions and physiological state of the phytoplankton host cells on their virus susceptibility and on the rate of virus proliferation. The main reason for this is of course that the number of phytoplankton host-virus systems that have ever been brought into culture and studied in the laboratory is low. Host-virus systems of Chlorella sp., Micromonas pusilla and Synechococcus $\mathrm{sp}$. have been studied for many years and are quite well known (Waters \& Chan 1982, Waterbury et al. 1986, Cottrell \& Suttle 1991, 1995, van Etten et al. 1991, Suttle \& Chan 1993, 1994, Waterbury \& Valois 1993). Viruses infecting Chrysochromulina brevifilum, Phaeocystis pouchetii and Heterosigma akashiwo have more recently been reported to be in culture and these systems await further investigation (Suttle \& Chan 1995, Jacobsen et al. 1996, Nagasaki \& Yamaguchi 1997). The Chlorella virus PBCV-1 has been found to replicate most efficiently in actively growing host cells and poorly in stationary-phase cells (van Etten et al. 1983, 1991). Investigating a marine Synechococcus host-virus system, Wilson et al. (1996) found that the length of the lytic cycle increased and the burst size decreased when cell growth was phosphate limited. In a marine mesocosm study, Bratbak et al. (1993) observed no virus production and no cell lysis of the coccolithophorid Emiliania huxleyi when phosphate was depleted. Availability of phosphate may thus seem to play a regulatory role for viral infection and lysis, at least for some algal host-virus systems. Nevertheless, there is a need for more and basic information on the physiology of the host cells in relation to viral infection that may provide a background for evaluating field observations.

The purpose of this study was to investigate the interaction between the marine haptophyte Phaeocystis pouchetii and its virus denoted PpV01 which recently has been brought into culture (Jacobsen et al. 1996). We have used experimental laboratory systems to address questions related to virus production and how it depends on host cells' physiological condition and environmental conditions such as nutrient ( $\mathrm{N}$ and P) and energy (light) availability. We developed a simple model describing the infection, the lysis of algae and the production of new viral particles.

\section{MATERIALS AND METHODS}

Cultures and medium. The algal host-virus system used in this study was Phaeocystis pouchetii (Prymnesiophyceae) strain AJ01 obtained from the culture collection at the University of Bergen, Norway, and the lytic virus PpV01 isolated from Raunefjorden, Western Norway (Jacobsen et al. 1996). This Phaeocystis strain does not form colonies under the growth conditions used in this study.

The cells were grown in a medium prepared from aged and autoclaved sea water $(33 \%)$ amended with vitamins and trace elements as for the $\mathrm{f} / 2$ medium (Guillard 1975). Nitrate and phosphate were added to

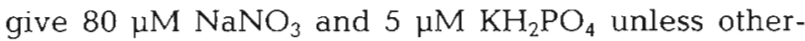
wise noted. The cultures were incubated at $8^{\circ} \mathrm{C}$ and in continuous white light of about 40 to $50 \mu \mathrm{mol} \mathrm{m} \mathrm{m}^{-2}$ $\mathrm{s}^{-1}$.

Enumeration of algae and virus. Growth of the algae was monitored by live cell counts in a Fuchs Rosenthal haematocytometer. Infective viruses were estimated by the most probable number (MPN) technique using cell-culture plates (Nuclon, Nunc Denmark) with 96 round bottom wells (Cottrell \& Suttle 1995). The virus solutions were diluted 10 -fold from $10^{-1}$ to $10^{-10}$ and $50 \mu \mathrm{l}$ of each dilution was then transferred to 8 parallel wells each containing $100 \mu \mathrm{l}$ of Phaeocystis culture in late exponential growth. Growth and lysis in the wells were recorded by visual inspection after $7 \mathrm{~d}$ of incubation at $8^{\circ} \mathrm{C}$ under continuous white light of about 40 to $50 \mu \mathrm{mol} \mathrm{m} \mathrm{m}^{-2} \mathrm{~s}^{-1}$.

Samples for total counting of virus were preserved with $2.5 \%$ glutaraldehyde. Particles were harvested onto electron microscope grids ( $\mathrm{Ni}, 400$ mesh) by centrifugation and prepared for counting in the transmission electron microscope (TEM) basically as described earlier (Bratbak \& Heldal 1993). To avoid overloading the grids when cell abundance was high, we used centrifuge tubes that were cut off to accommodate ca $3 \mathrm{ml}$ of sample water. The full length tubes were run for $1 \mathrm{~h}$ and the cut off tubes for $30 \mathrm{~min}$ at $200000 \times \mathrm{g}$ in a Beckman SW 41 swing-out rotor. The grids were positively stained with $2 \%$ uranyl acetate and viewed in a Jeol $100 \mathrm{CX}$ or a Jeol $100 \mathrm{~S}$ TEM at 20000 and $100000 \times$ magnification.

Culture experiments. Virus production in relation to algal growth phase: A volume of $250 \mathrm{ml}$ was withdrawn from a Phaeocystis pouchetii culture in (1) exponential, (2) early and (3) late stationary phase of growth and inoculated with $5 \mathrm{ml}$ of PpV01 virus lysate. The 3 infected subcultures were incubated as described above and the abundance of algae and viruses was monitored for $7 \mathrm{~d}$.

Nitrogen and phosphate requirements: A 1 l Phaeocystis pouchetii culture was incubated in a 21 Erlen- 
meyer flask until early stationary phase of growth split in 3 and diluted $1: 5$ in (1) complete medium, (2) medium without added phosphate and (3) medium without added nitrate. The total $\mathrm{N}$ and $\mathrm{P}$ content of the 3 cultures would thus be (1) $80 \mu \mathrm{M} \mathrm{N}$ and $5 \mu \mathrm{M} P(\mathrm{~N}: \mathrm{P}=$ 16:1), (2) $80 \mu \mathrm{M} \mathrm{N}$ and $1 \mu \mathrm{M} P(\mathrm{~N}: \mathrm{P}=80: 1$ ), and (3) $16 \mu \mathrm{MN}$ and $5 \mu \mathrm{MP}(\mathrm{N}: \mathrm{P}=3.2: 1)$ respectively. After $8 \mathrm{~d}$ of incubation the culture growing in complete medium was diluted 1:3 (in complete medium) to obtain a cell density comparable to the nutrient deficient cultures (see Fig. 2a). After $9.7 \mathrm{~d}$ of incubation, when the nutrient deficient cultures had reached stationary phase of growth (see Fig. 2a), we split each of the 3 cultures into 4 subcultures of $200 \mathrm{ml}$ contained in $0.5 \mathrm{l}$ Erlenmeyer flasks. For each set of subcultures, 2 received $50 \mu$ of PpV01 virus lysate while the other 2 served as non-infected controls. Theoretically the lysate addition increased the nitrate and phosphate concentration in the cultures by no more than $20 \mathrm{nMN}$ and $1.25 \mathrm{nM}$ P. The abundance of algae, viruses and bacteria was monitored for $4 \mathrm{~d}$ as described above.

Light requirements: An exponentially growing Phaeocystis pouchetii culture was split into 2 equal aliquots. One aliquot of $800 \mathrm{ml}$ was further split into 4 cultures of $200 \mathrm{ml}$ in $0.5 \mathrm{l}$ Erlenmeyer flasks. The other aliquot received $10 \mathrm{ml}$ of a fresh PpV01 lysate and was then split into 4 cultures as above. Two of the infected cultures and 2 of the non-infected cultures were incubated under the light conditions described while the remaining ( 2 infected and 2 noninfected) cultures were incubated in the dark, i.e. they were wrapped in several layers of black plastic and aluminum foil. The abundance of algae, viruses and bacteria was monitored for $6 \mathrm{~d}$ as described above.

Multiplicity of infection (MOI): A Phaeocystis pouchetii culture in exponential growth was split in 3 and inoculated with 3 different concentrations of PpV01 virus. The 3 infected subcultures were incubated as described above and the abundance of algae and viruses was monitored for $7 \mathrm{~d}$. In this case the viruses were counted in an epifluorescence microscope after filtration onto $0.02 \mu \mathrm{m}$ pore size Anodisc filters (Whatman) and staining with DAPI (Porter \& Feig 1980).

Simulation model for host-virus dynamics. As an aid for analyzing and understanding the phytoplankton host-virus interaction we developed a simple model describing the infection, the lysis of algae and the production of new viral particles.

For the contact rate between virus and host cells we determined a volume clearance rate per particle $(c)$ as described by Murray \& Jackson (1992). The size of the PpV01 virus used in our experiments was $150 \mathrm{~nm}$ (Jacobsen et al. 1996) and its diffusivity at $8^{\circ} \mathrm{C}$ was thus calculated as $2 \times 10^{-8} \mathrm{~cm}^{2} \mathrm{~s}^{-1}$. For flagellates that are $5 \mu \mathrm{m}$ in diameter (see 'Results') we estimated the volume clearance rate per particle to be $5.7 \times 10^{-7} \mathrm{ml} \mathrm{h}^{-1}$ for motile host cells and $2.3 \times 10^{-7} \mathrm{ml} \mathrm{h}^{-1}$ for non-motile host cells. These rates are valid for an ideal system with $100 \%$ adsorption and infection. To allow for suboptimal host-virus systems we regarded this as a maximum contact rate and assumed that virus adsorbing to a host cell was a fraction $\left(\sigma_{1}\right)$ of the viruses colliding with the cell and that virus infecting a host cell was a fraction $\left(\sigma_{2}\right)$ of the viruses adsorbing to the cell. Symbols are summarized in Table 1 .

Change in the abundance of uninfected algae $(A)$ is determined by growth minus infection:

$$
\mathrm{d} A / \mathrm{d} t=\mu A-C \sigma_{1} \sigma_{2} V A
$$

Change in the abundance of infected cells $(I)$ is determined by infection minus cell lysis which is a function of the number of cells infected at time $t-\tau$, where $\tau$ is the length of the lytic cycle

$$
\mathrm{d} I / \mathrm{d} t=c \sigma_{1} \sigma_{2} V A-c \sigma_{1} \sigma_{2} V_{t-\tau} A_{t-\tau}
$$

\begin{tabular}{|c|c|c|c|}
\hline Symbol & Explanation & Unit & Values used \\
\hline$A$ & Algal cells & Cells $\mathrm{ml}^{-1}$ & \\
\hline$I$ & Virus infected algal cells & Cells $\mathrm{ml}^{-1}$ & \\
\hline$V$ & Virus particles & Viruses $\mathrm{ml}^{-1}$ & \\
\hline$t$ & Time & $\mathrm{h}$ & \\
\hline$\mu$ & Specific growth rate of the algae & $h^{-1}$ & $0.015 \mathrm{~h}^{-1}$ \\
\hline$m$ & Viral particles released per lysed aIgal cell (burst size) & Viruses cell ${ }^{-1}$ & 400 \\
\hline$c$ & Maximum host virus contact rate $=$ volume clearance rate per particle & $\mathrm{ml} \mathrm{h}^{-1}$ & $\begin{array}{l}\text { Motile host cells: } 5.7 \times 10^{-7} \\
\text { Non-motile host cells: } 2.3 \times 10^{-7}\end{array}$ \\
\hline$\sigma_{1}$ & Fraction of viruses adsorbed upon contact with a host cell & - & $100 \%$ and $10 \%$ \\
\hline$\sigma_{2}$ & Fraction of infective viruses & - & $8 \%$ \\
\hline$\tau$ & Time between infection and lysis of a cell (lytic cycle) & h & 15 \\
\hline$\gamma$ & Decay rate for virus & $\mathrm{h}^{-1}$ & 0 \\
\hline
\end{tabular}

Table 1. Definition of symbols and values used in the model 
Change in the abundance of virus $(V)$ is determined by cell lysis times the burst size, minus adsorption of viruses to both infected and uninfected algae, minus decay of viral particles:

$$
\mathrm{d} V / \mathrm{d} t=m c \sigma_{1} \sigma_{2} V, A_{t-\tau}-c \sigma_{1} V(A+I)-\gamma V
$$

The model was programmed and solved numerically using the Stella II modeling software.

\section{RESULTS}

\section{Virus production in relation to algal growth phase}

The number of viruses added to the Phaeocystis culture in exponential, early stationary and late stationary-senescence phase of growth was 4 to 6 virus particles per algal cell. Fig. 1a shows that Phaeocystis was sensitive to virus infection in all phases of growth and that the population was decimated within $3 \mathrm{~d}$ after virus infection. From the decrease in cell abundance and the concurrent increase in viral abundance we estimate the burst size of the algal cells in exponential and in early stationary phase of growth to be 240 and 180 viruses cell ${ }^{-1}$, respectively (Fig. 1a, b). In late sta-

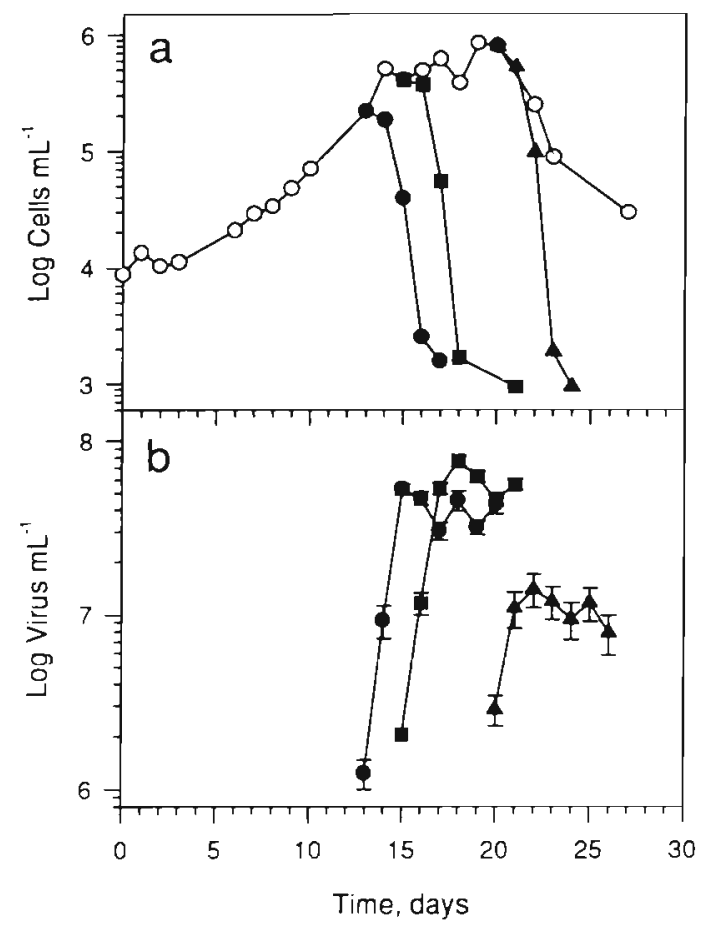

Fig. 1. Virus infection in Phaeocystis pouchetii at different stages of growth. (a) Cells, (b) viruses. Non-infected culture (O). Subcultures infected in exponential phase (-), in early stationary phase (ם), and in late stationary phase (A). Error bars on virus counts are counting error. $(1 / \mathrm{V} n, n=$ number of viruses counted tionary phase, the burst size was significantly less, about 15 viruses cell ${ }^{-1}$

\section{Nitrogen and phosphate requirements}

Fig. 2a shows that Phaeocystis in the complete medium culture was growing exponentially and that Phaeocystis in the 2 nutrient deficient cultures had entered stationary phase when the cultures were split and viruses added. Growth in the control cultures which received no viruses continued as before the split, i.e. cell abundance increased in the complete medium cultures while it remained stable in the nutrient deficient cultures (Fig. 2b). The virus infected cultures showed complete lysis within 3 to $4 \mathrm{~d}$. Cell lysis (Fig. 2b) and release of new viruses (Fig. 2c) appeared to be more rapid in the complete medium cultures compared to the nutrient deficient cultures (Fig. 2b, c). From net change in cell and virus abundance between Days 11.7 and 12.7 we estimate the mean burst size to be 130 in the complete medium cultures and about 70 in the nutrient deficient cultures.

\section{Light requirements}

The non-infected control cultures behaved as expected (Fig. 3a). Phaeocystis grew well in light while no change in cell abundance occurred in the dark. Fig. 3b shows that cell lysis was more rapid and more complete, and that the virus production was much higher in the cultures incubated in light compared to those incubated in darkness. The mean burst size of the cells was about 370 viruses per algal cell in light and about 100 viruses per algal cell in the dark.

\section{Infectivity and multiplicity of infection}

From a number of different experiments and cultures (including many not shown and discussed here) we sampled simultaneously for total counts and infective counts (i.e. most probable number) of viruses. The number of infective particles in fresh algal lysates varied from 7 to $100 \%$ of the total counts (mean $\pm \mathrm{SD}=$ $60 \pm 60 \%, n=13$ )

The effect of varying the multiplicity of infection (MOI) is shown in Fig. 4 a. The number of virus particles added per algal cell to the 3 cultures was $0.15,2$ and 50. The number of infective virus particles in the inoculum, as determined by most probable number, was however for this experiment found to be only $8 \%$ of the total virus counts. The MOI for the 3 cultures 

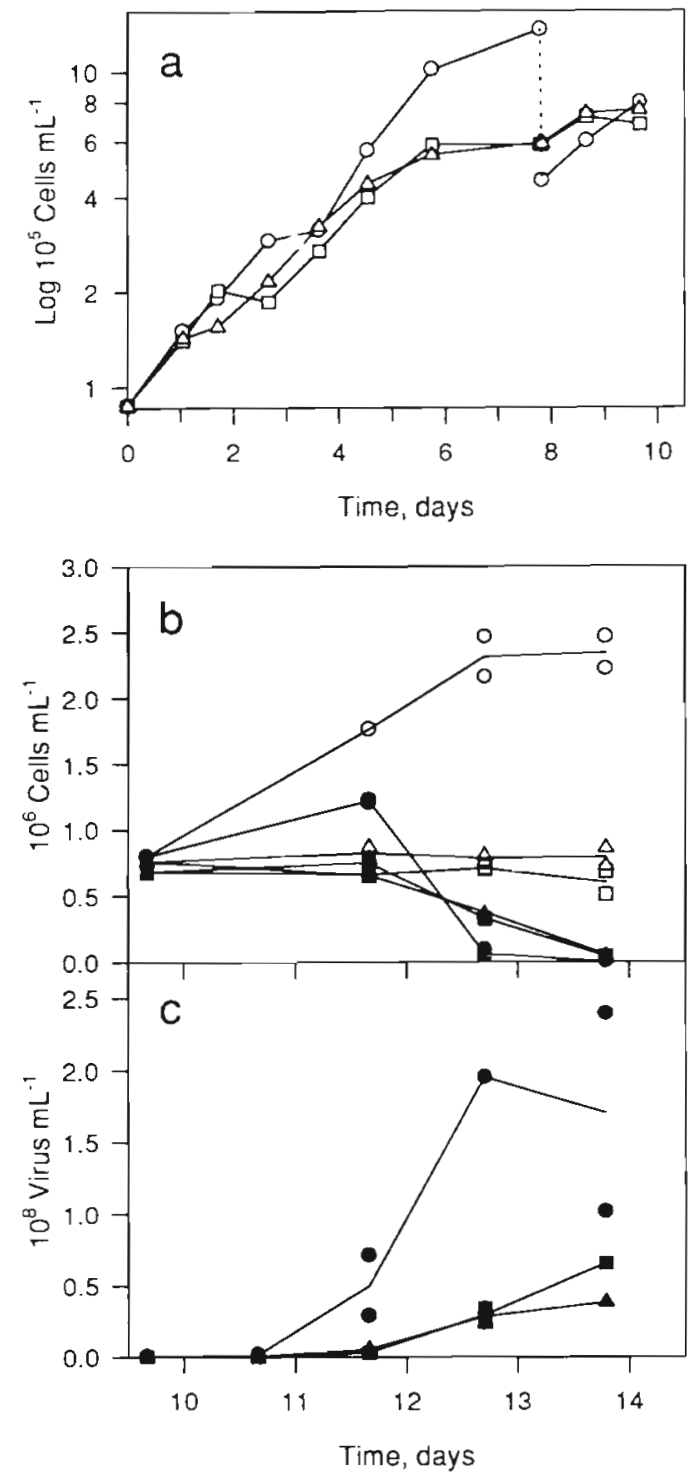

Fig. 2. Virus production in Phaeocystis pouchetii growing in batch cultures under different nutrient regimes. (a) Batch cultures of $P$. pouchetii growing in complete medium $(O)$, in low nitrogen medium $(\square)$ and in low phosphate medium $(\Delta)$. After $7.8 \mathrm{~d}$ the culture growing in complete medium was diluted $1: 3$ (in complete medium). After $9.7 \mathrm{~d}$ of incubation each of the cultures was split into 4 subcultures of which 2 were infected with virus and 2 served as non-infected controls. (b) Change in abundance of $P$. pouchetii in non-infected control cultures (open symbols) and virus infected cuitures (filled symbols). (c) Virus production in virus infected $P$. pouchetii cultures. The symbols denote the same nutrient regimes in all figures

was thus about $0.01,0.2$ and 4 , respectively. The mean burst size of the cells in the 3 cultures was found to be 510,290 and 320 viruses per algal cell, respectively.

Fig. 4a shows that a higher initial MOI results in an earlier decline in algal abundance. The rate of decrease in algal abundance and the rate of increase in

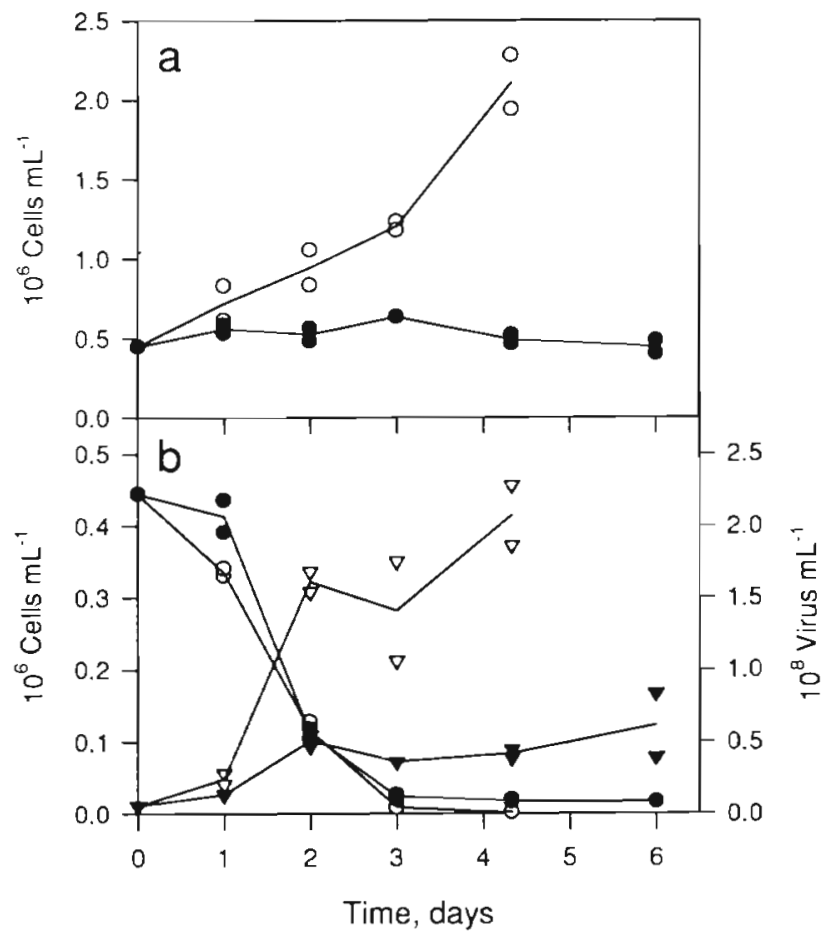

Fig. 3. Virus production in Phaeocystis pouchetii under different light regimes. (a) Change in abundance of $P$. pouchetii in non-infected control cultures incubated in light $(O)$ and in darkness (b). (b) Change in abundance of $P$. pouchetii (circles) and virus (triangles) in infected cultures incubated in light (open symbols) and in darkness (filled symbols). All incubations included 2 parallel cultures

viral abundance was however not affected. A low initial MOI $(<1)$ gave a higher viral yield because the algal population increased in abundance before all cells were infected and lysed.

\section{Simulation of host-virus dynamics}

The data from the MOl experiment were used as input parameters to the simulation model. The numerical solution of the model, assuming the cells to be motile or non-motile, and the virus absorption efficiency to be 100 or $10 \%$, is shown in Fig. 4 b, c, d. With $100 \%$ adsorption efficiency the model predicts a faster change in algal and viral abundance than was observed experimentally (Fig. 4b). With 10\% absorption efficiency the model simulates the experimental results quite well (Fig. 4c, d). With motile cells the increase in viruses is on time with the experimental data but the algae diminish too early in the model (Fig. 4c). With non-motile cells (Fig. 4d) the increase in the virus abundance is slower than in the experiment while the algae diminish on time with the experimental results. In any case the model predicts a more sud- 


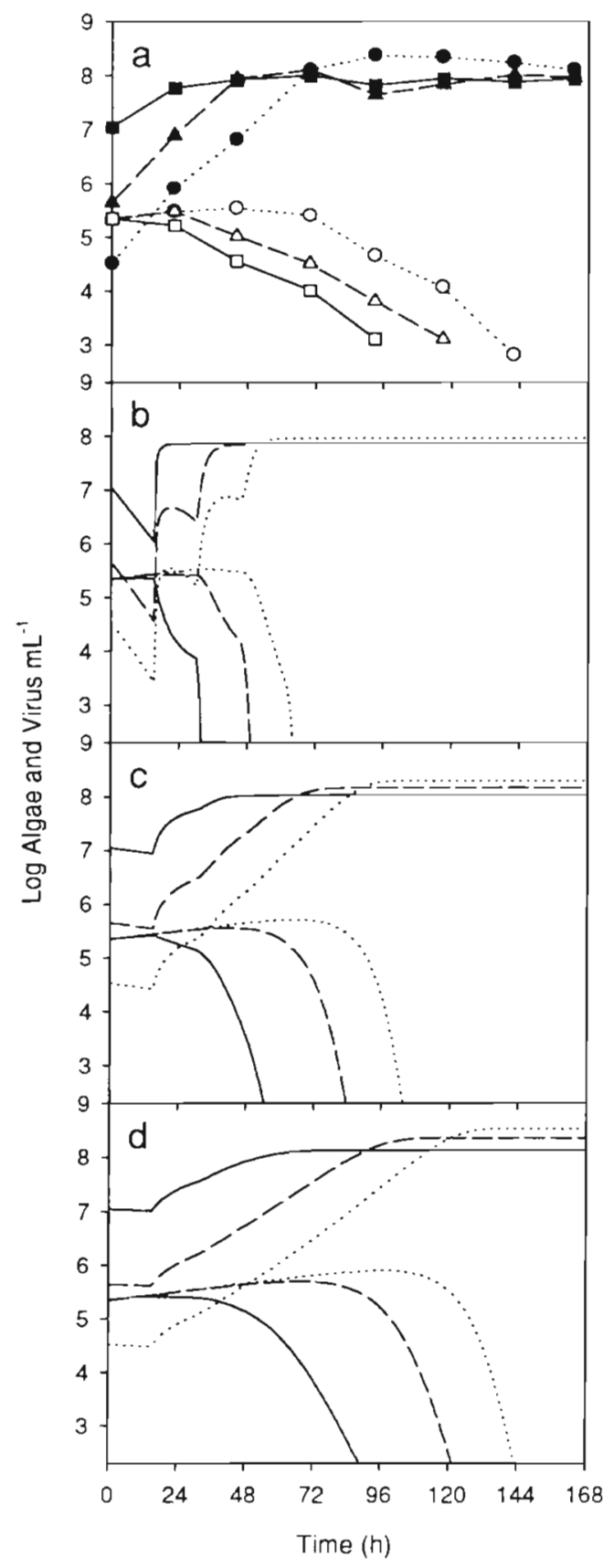

Fig. 4. (a) Experimental data and (b, c, d) simulation model output demonstrating the effect of varying the multiplicity of infection (MOI), the effect of 'efficient' (i.e. 100\%) and 'inefficient' (i.e. $10 \%$ ) virus adsorption to the host cells, and the effect of host cell motility on cell lysis and virus production. (a) Change in abundance of Phaeocystis pouchetii (open symbols) and virus (closed symbols) at an initial virus-to-host ratio of 0.15 (circles), 2 (triangles), and 50 (squares). (b) Simulation model with motile cells and $100 \%$ adsorption efficiency, (c) simulation model with motile cells and $10 \%$ adsorption efficiency, (d) simulation model with non-motile cells and $10 \%$ adsorption efficiency. The lines in $(b, c, d)$ indicate change in abundance of host cells and virus at different initial virus-to-host ratios and they may be identified by comparison with lines and symbols used in (a) den decrease in algal abundance than we observed experimentally. The experimental observation that a low initial MOI results in a higher viral yield because the algal population increased in abundance before all cells were infected and lysed was also predicted by the model (Fig. 4c, d).

The effect of the burst size $(m)$, the length of the lytic cycle $(\tau)$, the host growth rate $(\mu)$ and the infectivity of the viruses $\left(\sigma_{2}\right)$ on host-virus dynamics was simulated and the results are shown in Fig. 5. The effects of increasing the burst size (Fig. 5a) were earlier collapse of the algal population, earlier increase in virus, and higher virus yield. A longer lytic cycle (Fig. 5b) delayed cell lysis and virus production. Increasing the host's growth rate (Fig. 5c) gave a higher host density before the collapse and a correspondingly higher yield of virus. The timing of cell lysis was however only slightly affected. The effect of increasing the fraction of infective viruses (Fig. 5d) was an earlier collapse of the algal population, and consequently lower maximum host density and virus yield.

\section{DISCUSSION}

The main conclusions that can be drawn from these experiments are that Phaeocystis pouchetii was susceptible to virus infection in all stages of growth and that nutrient (nitrate or phosphate) or light limitation of algal growth did not prevent viral reproduction and cell lysis. Phosphate availability thus did not play the same important regulatory role in virus replication in this system as it has been suggested to do for other algal host-virus systems (Bratbak et al. 1993, Wilson et al. 1996). The physiological reason for this apparent difference is unknown, but it has some interesting ecological implications in that some species may have a selective advantage of not being vulnerable to virus infection under P limiting conditions. If, as an example, P. pouchetii and Emiliania huxleyi are blooming in the same water mass and exhaust the phosphorus supply, $P$. pouchetii may experience a viral attack, lyse and release its rutrient content to the benefit of the $E$. huxleyi population which is less vulnerable to viral infection due to the $\mathrm{P}$ limitation.

In the growth stage (Fig. 1), nutrient depletion (Fig. 2) and dark incubation (Fig. 3) experiments the first increase in virus concentration was observed within $24 \mathrm{~h}$, and lysis of the algal culture was complete within 3 to $4 \mathrm{~d}$. The Phaeocystis pouchetii-PpV01 hostvirus system has a lytic cycle of 12 to $18 \mathrm{~h}$ (Jacobsen et al. 1996), indicating that the cultures in the present study underwent at least 1 cycle of infection and virus replication before the virus titer was high enough to infect all cells and cause a complete lysis of the culture. 


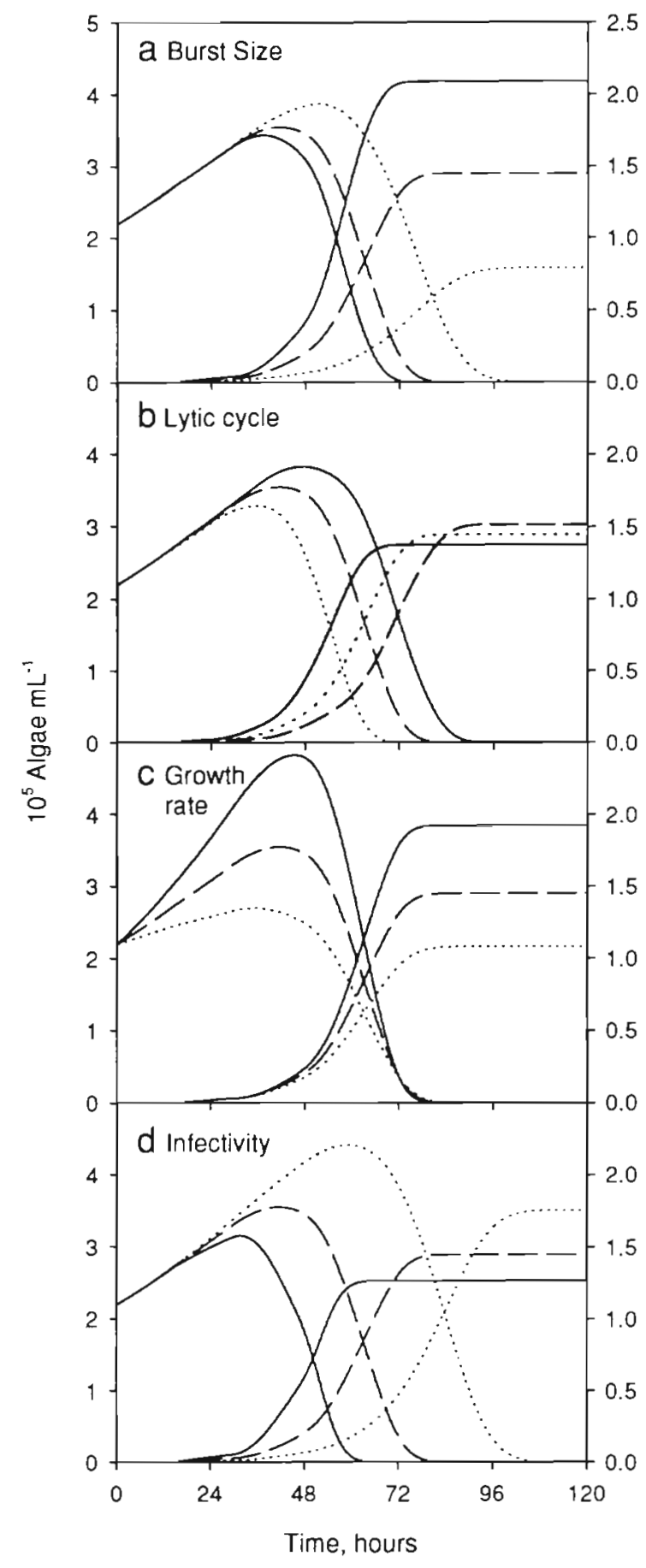

Fig. 5. Simulation of the effect of burst size $(m)$, length of the lytic cycle $(\tau)$, host growth rate $(\mu)$ and infectivity of the viruses $\left(\sigma_{2}\right)$ on host-virus dynamics. The model was run assuming the cells to be motile, the viruses to have a $10 \%$ absorption efficiency and the MOI to be 2 (cf. Table 1, Fig. 4c). (a) Burst size $m=200,400$ and 600, (b) lytic cycle $\tau=12,15$ and $18 \mathrm{~h},(\mathrm{c})$ host growth rate $\mu=0.0075,0.015$ and $0.0225 \mathrm{~h}^{-1}$ and (d) virus infectivity $\sigma_{2}=4,8$ and $12 \%$. Intermediate parameter values ( $m=400, \tau=15 \mathrm{~h}, \mu=0.015 \mathrm{~h}^{-1}$ and $\sigma_{2}=8 \%$ ) were used throughout unless otherwise noted. Simulations with high, intermediate and low values are indicated with a continuous line, a dashed line and a dotted line respectively
From these observations we cannot conclude that growth stage, nutrient or light limitation of the algal host cells did result in a prolonged latent period as might have been expected. The time resolution of our experiments is determined by our $24 \mathrm{~h}$ sampling interval and any prolongation must have been at least about 6 h before we could detect it. In contrast to our observation Wilson et al. (1996) found that complete lysis of a virus infected Synechococcus was delayed for $18 \mathrm{~h}$ under phosphorus depleted conditions as compared to nutrient replete conditions.

The average number of viruses produced in each host cell was found to vary from 15 to 510 . The highest values compare to earlier observations of 350 to 600 viral particles per lysed cell (Jacobsen et al. 1996). Lowest numbers were found in non-growing cultures, i.e. in stationary phase cultures, in nutrient depleted cultures and in light limited cultures, while the highest were found in exponentially growing cultures. The physiological condition of the cells does thus obviously have an impact on the virus production. Whether or not nutrient limitation as such affects the number of viruses produced in a cell directly or only indirectly by causing inferior cellular growth is however yet unclear. Nevertheless, these observations agree qualitatively with earlier observations. The Chlorella virus PBCV-1 replicates most efficiently in actively growing host cells and poorly in stationary-phase cells (van Etten et al. 1983, 1991). In the dark, the burst size of this hostvirus system is reduced by $50 \%$ (van Etten et al. 1983). Burst size of virus infected Synechococcus was reduced by $80 \%$ under phosphorus depleted conditions as compared to nutrient replete conditions (Wilson et al. 1996).

The infectivity of the progeny viruses produced indicated a large variation, from 7 to $100 \%$ of total counts. In comparison, Cottrell \& Suttle (1995) found that MPN counts of the $M p V$-SP1 virus infecting Micromonas pusilla were 12 to $34 \%$ of total virus counts, and van Etten et al. (1991) estimated the infectivity of the PBCV-1 virus of Chlorella to be 25 to $50 \%$. We were not able to reveal any relationship between the physiological status or growth condition of the host cells and the infectivity of the viruses. The confidence limits of the MPN method are however relatively large even with 8 parallel dilutions. On the average the low and high $95 \%$ confidence limits were 45 and $220 \%$ of the MPN value. Statistical uncertainty may thus have confounded the detection of a possible relationship.

The features and the dynamics of the host-virus interaction were in general quite well simulated by the model. It is noteworthy that the model requires a relatively low host-virus adsorption efficiency $(10 \%)$ in order to produce a reasonably good fit between simulation and experimental observations. The main differ- 
ence between data and model was that the model predicts a more sudden decrease in algal abundance than was observed experimentally. Running the model with different parameter settings (Fig. 5) shows that a change in burst size $(m)$, length of the lytic cycle $(\tau)$, host growth rate $(\mu)$ or infectivity of the viruses $\left(\sigma_{2}\right)$ would not result in a better fit between model and data. A slower decrease in algal abundance would however be obtained if the burst size or the infectivity decreased, or the length of the lytic cycle increased with time throughout the experiment. An increasing virus abundance and MOI may be hypothesized to result in earlier and premature lysis, and thus in low burst size, cf. 'lysis from without' for bacteria (Stent 1963). A biological or experimental rationale for introducing variations in the other parameters is lacking. Another explanation for the difference between data and model may be that cells that lyse and release viruses do not disintegrate immediately, as implicitly assumed in the model, but stay intact for some time and are included in the algal counts.

The ecological implication of these experimental findings is that burst size and the potential for virus reproduction may be expected to be highest early in a bloom situation when growth and nutritional conditions are favorable. The abundance of host cells may however be too low early in the bloom for efficient reinfection and reproduction of virus. The bloom may thus develop with minor loss of cells until a concentration is reached when the abundance of hosts is conducive to high rates of virus reproduction and the MOI becomes $>1$ so that all hosts are infected and the bloom collapses. The virus-to-host ratio obtained in the model (Fig. 5) at the peak of the algal abundance just before the population collapsed was 17 to 38 , which corresponds to 1.4 to 3.2 infective particles per host. Under natural conditions, however, other factors than the abundance of host and virus may also be important. Phaeocystis blooming in natural waters often form colonies where the cells are embedded in mucoid material (Lancelot et al. 1987). If we hypothesize that the mucus makes the cells inaccessible to viral infection this may explain why Phaeocystis in the colonial stage is able to form dense blooms, apparently without any major loss of cells due to viral lysis.

The eucaryotic micoalgal host-virus systems we and others have investigated are all lytic systems. Some of the factors regulating virus production and activity in these systems have been investigated experimentally and we may hypothesize that the same factors play some significant role in situ. It may however be that virus production in situ is regulated through latent infection of the algal host as well as by lytic infection in the same way as bacteriophage production in natural systems may be regulated through lysogenic host- virus systems (Jiang \& Paul 1994, 1996) as well as by lytic infection (Wilcox \& Fuhrman 1994).

Acknowledgements. This work was supported by funding from The European Commission to the MAST-III Project MEDEA, contract number MAS3-CT95-0016 and by funding from The Research Council of Norway, project number $113037 / 120$ and 121425/420. We thank Evy Foss Skjoldal, Jorunn Viken and Gunhild Bodtker for their excellent technical assistance. The EM work was done at the Laboratory for Electron Microscopy, University of Bergen.

\section{LITERATURE CITED}

Bratbak G, Egge JK, Heldal M (1993) Viral mortality of the marine alga Emiliania huxleyi (Haptophyceae) and termination of algal blooms. Mar Ecol Prog Ser 93:39-48

Bratbak G, Heldal M (1993) Total count of viruses in aquatic environments In: Kemp PF, Sherr BF, Sherr EB, Cole JJ (eds) Current methods in aquatic microbial ecology. Lewis Publishers, London, p 135-138

Bratbak G, Heldal M, Norland S, Thingstad TF (1990) Viruses as partners in spring bloom microbial trophodynamics. Appl Environ Microbiol 56:1400-1405

Bratbak G, Levasseur M, Michaud S, Cantin G, Fernández E, Heimdal BR, Heldal M (1995) Viral activity in relation to Emiliania huxleyi blooms: a possible mechanism of DMSP release? Mar Ecol Prog Ser 128:133-142

Brussaard CPD, Riegman R, Noordeloos AA, Cadée GC, Witte $H$, Kop AJ, Nieuwland G, van Duyl FC, Bak RPM (1995) Effects of grazing, sedimentation and phytoplankton cell lysis on the structure of a coastal pelagic food web. Mar Ecol Prog Ser 123:259-271

Cottrell MT, Suttle CA (1991) Wide-spread occurrence and clonal variation in viruses which cause lysis of a cosmopolitan eucaryotic marine phytoplankter, Micromonas pusilla. Mar Ecol Prog Ser 78:1-9

Cottrell MT, Suttle CA (1995) Dynamics of a lytic virus infecting the photosynthetic marine picoflagellate Micromonas pusilla. Limnol Oceanogr 40:730-739

Fuhrman JA, Suttle CA (1993) Viruses in marine planktonic systems. Oceanography 6(2):51-63

Guillard RRL (1975) Culture of phytoplankton for feeding marine invertebrates. In: Smith WL, Chanley MH (eds) Culture of marine invertebrate animals. Plenum Press, New York, p 29-60

Jacobsen A, Bratbak G, Heldal M (1996) Isolation and characterisation of a virus infecting Phaeocystis pouchetii (Prymnesiophyceae). J Phycol 32:923-927

Jiang SC, Paul JH (1994) Seasonal and diel abundance of viruses and occurence of lysogeny/bacteriocinogeny in the marine environment. Mar Ecol Prog Ser 104:163-172

Jiang SC, Paul JH (1.996) Occurrence of lysogenic bacteria in marine microbial communities as determined by prophage induction. Mar Ecol Prog Ser 142:27-38

Lancelot C, Billen G, Sournia A, Weisse T, Colijn F, Veldhuis M, Davies A, Wassmann P (1987) Phaeocystis blooms and nutrient enrichment in the continental coastal zones of the North Sea. Ambio 16:38-46

Maranger R, Bird DF (1995) Viral abundance in aquatic systems: a comparison between marine and fresh waters. Mar Ecol Prog Ser 121:217-226

Murray AG, Jackson GA (1992) Viral dynamics: a model of the effects of size, shape, motion and abundance of singlecelled planktonic organisms and other particles. Mar Ecol Prog Ser 89:103-1.16 
Nagasaki K, Yamaguchi M (1997) Isolation of a virus infectious to the harmtul bloom causing microalga Heterosigma akashiwo (Raphidophyceae). Aquat Microb Ecol 13:135-140

Porter KG, Feig YS (1980) The use of DAPI for identifying and counting aquatic microflora. Limnol Oceanogr 25:943-948

Proctor LM, Fuhrman JA (1990) Viral mortality of marine bacteria and cyanobacteria. Nature 343:60-62

Reisser W (1993) Viruses and virus-like particles of freshwater and marine eucaryotic algae-a review. Arch Protistenkd 143:257-265

Stent GS (1963) Molecular biology of bacterial viruses. Freeman and Company, San Francisco

Suttle CA (1992) Inhibition of photosynthesis in phytoplankton by the submicron size fraction concentrated from seawater. Mar Ecol Prog Ser 87:105-112

Suttle CA, Chan AM (1993) Marine cyanophages infecting oceanic and coastal strains of Synechococcus: abundance, morphology, cross-infectivity and growth characteristics. Mar Ecol Prog Ser 92:99-109

Suttle CA, Chan AM (1994) Dynamics and distribution of cyanophages and their effect on marine Synechococcus spp. Appl Environ Microbiol 60:3167-3174

Suttle CA. Chan AM (1995) Viruses infecting the marine prymnesiophyte Chrysochromulina spp.: isolation preliminary characterization and natural abundance. Mar Ecol Prog Ser 118:275-282

Suttle CA, Chan AM, Cottrell MT (1990) Infection of phytoplankton by viruses and reduction of primary productivity. Nature 347:467-469

Thingstad TF, Heldal M, Bratbak G, Dundas I (1993) Are viruses important partners in pelagic food webs? Trends Ecol Evol 8:209-213

Editorial responsibility: John Dolan, Villefranche-sur-Mer, France van Etten JL, Burbank DE, Xia Y, Meints RH (1983) Growth cycle of a virus, PBCV-1, that infects Chlorella-like algae. Virology 126:117-125

van Etten JL, Lane LC, Meints RH (1991) Viruses and viruslike particles of eucaryotic algae. Microbiol Rev 55: $586-620$

Walsby AF, Reynolds CS (1980) Sinking and floating. In Morris l (ed) The physiological ecology of phytoplankton. Blackwell Scientific Publications, Oxford, p 371-412

Walsh JJ (1983) Death in the sea: enigmatic phytoplankton losses. Prog Oceanogr 12:1-86

Waterbury JB, Valois FW (1993) Resistance to co-occurring phages enables marine Synechococcus communities to coexist with cyanophages abundant in seawater. Appl Environ Microbiol 59:3393-3399

Waterbury JB, Watson SW, Valois FW, Franks DG (1986) Biological and ecological characterization of the marine unicellular cyanobacterium Synechococcus. Can Bull Fish Aquat Sci 214:71-120

Waters RE, Chan AT (1982) Micromonas pusilla virus: the virus growth cycle and associated physiological events within the host cells; host range mutation. J Gen Virol 63 : 199-206

Wilcox RM, Fuhrman JA (1994) Bacterial viruses in coastal seawater: lytic rather than lysogenic production. Mar Ecol Prog Ser 114:35-45

Wilson, WH, Carr NG, Mann NH (1996) The effect of phosphate status on the kinetics of cyanophage infection in the oceanic cyanobacterium Synechococcus sp. WH7803. J Phycol 32:506-516

Zingone A (1995) The role of viruses in the dynamics of phytoplankton blooms. G Bot Ital 129:415-423

Submitted: March 31, 1998; Accepted: May 29, 1998

Proofs received from author(s): September 29, 1998 